\title{
Incorporation of Environmental and Sustainable Indicators in Universities
}

\author{
Lourdes Ruiz \\ International University of Ecuador, Quito, Ecuador \\ Email: Iruiz@internacional.edu.ec
}

Received 9 March 2016; accepted 9 May 2016; published 12 May 2016

Copyright (C) 2016 by author and Scientific Research Publishing Inc.

This work is licensed under the Creative Commons Attribution International License (CC BY). http://creativecommons.org/licenses/by/4.0/

(c) (;) 0pen Access

\section{Abstract}

The use of environmental and sustainable indicators of global organizations has greater advantages than those of national initiatives or those developed by researchers in said subject, due to the fact that they have a much broader scope for sustainability, have been applied in a systematic manner and therefore have greater comparability and reliability. The environmental indicators are constructed from the approaches to sustainable development in universities with regards to the social, economic, institutional and environmental dimensions in the organizations. This work involves the application of environmental and sustainable indicators for internationally recognized efficiency in university activities, which contribute towards organizing, summarizing and developing the processes for development planning and environmental management.

\section{Keywords}

\section{Indicators, Environment, Sustainable, Universities}

\section{Introduction}

The indicators are measurements, the purpose of which is to reduce a large quantity of data which at the same time represents a phenomenon larger than the quality or immediate value and thus the data become more meaningful by making it more manageable and accessible.

The indicators measure the information in such a way that it becomes immediately visible and simplifies it for the complex phenomena, thereby facilitating communication. They provide information relevant to society, which is not immediately perceptible, giving an implicit or explicit set of signs about the course of events of interest.

The university institutions should act as a model for learning and practice for sustainable development, from two perspectives, from the point of view of behavior of the institution itself and the impact of the activities 
undertaken (teaching, research and management) and from the point of view of the impact of their activity on the rest of society in an environment where higher education, research and innovation are considered to be key factors for facing the challenges of globalization and of a society based on the knowledge which guarantees the well-being of the citizens and sustainable development [1].

Unlike environmental indicators, the sustainable indicators indicate higher value-added information, that is to say, they constitute transversal indicators, which inform on the social, economic, institutional and environmental areas of any organization. There are successful experiences in various universities around the world:

- University sustainability reporting: the analysis focuses primarily on the Global Reporting Initiative (GRI) index. The paper finds that those universities which have adopted the GRI share a distinct conceptualisation of their role in society. The GRI framework is helpful in capturing universities' environmental impacts and benefits, but is lacking in relation to universities' human rights and social concerns [2].

- The International Sustainable Campus Network (ISCN-GULF being the English acronym), which is a select forum which incorporates the best practices for sustainability, where there are only 37 member universities in the world and the Latin American region, only 3 universities: the Instituto Tecnológico de Monterrey [Technological Institute of Monterrey], la Pontificia Universidad Católica del Perú [the Pontifical Catholic University of Peru] and the Universidad Internacional del Ecuador [International University of Ecuador] [3].

- The Global Universities Partnership on Environment for Sustainability (GUPES being the acronym in English) sponsored by the United Nations Environment Program (UNEP). GUPES will provide universities with a platform to interact with policy-makers and others within the UN Environment Programme (UNEP) and other international organizations as well as with one another specifically on sustainability issues [4].

- The Alliance of Ibero-American Universities Network for Sustainability and the Environment (ARIUSA), where the Network of Indicators for Sustainability in Universities (RISU) managed in Spain and the Mexican Consortium for University Environment Programs for Sustainable Development (COMPLEXUS being the Spanish acronym) stand out [5].

The main premise for selecting environmental indicators, is knowing what information is available and from that what is really useful for informing quickly and reliably. In this respect, even though there are various lists of indicators, it is recommended that each institution adapts or creates its own indicators in accordance with its specific characteristics.

The environmental indicators in universities allow the information to be organized summarized and processed, making known the objectives and the goals of the institutional policies and they are essential for making well informed decision and in the planning processes for development and environmental management.

The development of environmental indications is a growing issue and extremely topical in the International arena. During this decade, various countries and organizations in the world have drawn up goals in order to achieve them. For universities this constitutes an important tool for measuring the progress towards sustainability.

\section{Research Methodology}

The ethical duty of the university involves adopting a sustainability model, which has an impact in all areas of action and influence. For this reason, there are various initiatives in the international context, which have proposed environmental indicators in universities. On a regional level, there are numerous organizations which stand out as a result of their conceptual contribution applied in this area. Amongst the universities comprising the Network of University Sustainability Indicators are:

- Universidad de Ciencias Aplicadas y Ambientales [University of Applied and EnvironmentalSciences]

- Universidad Tecnológica de Pereira [Pereira TechnologicalUniversity]

- Universidad Autónoma de Madrid [AutonomousUniversity of Madrid]

- Universidad Earth [Earth university]

- Universidad Nacional de Quilmes [National University of Quilmes]

- Universidad de Valparaiso [ValparaisoUniversity]

- Universidades de México [Universities of Mexico]

- Universidad Valle de Itajaí [Valle de ItajaíUniversity]

- Instituto Superior de Tecnologías y Ciencias Aplicadas [Higher Institute of Technology and Applied Sciences]

- Instituto Tecnológico de Santo Domingo [TechnologicalInstitute of Santo Domingo]

- Universidad Internacional del Ecuador 
Currently the Alliance of Ibero-American Universities Network for Sustainability and the Environment (ARIUSA) coordinates a working group between universities and the Network of Indicators for Sustainability in Universities (RISU), the aim of which is to develop and implement them in the universities comprising the aforementioned Alliance. These constitute a benchmark for Ibero-American universities [6].

The main premise for selecting environmental indicators, is knowing what information is available and from that what is really useful for informing quickly and reliably. In this respect, even though there are various lists of indicators, it is recommended that each institution adapts or creates its own indicators in accordance with its specific characteristics.

Diagnostics should be performed at each university, which should use reliable data or be illustrated with representative examples to measure the progress in the process of incorporating the sustainability issues in the four basic functions [6]:

1) Research: sustainability in scientific research.

2) Education: undergraduate and graduate training for sustainability

3) Extension: university extension in sustainability issues.

4) Administration: sustainable and environmental management systems

- Research: sustainability in scientific research.

This incorporates the environmental research in the centers, programs or university groups that are most renowned within the national and international scientific community which stand out due to their linking their work with the solution of existing problems, by the consultancy and advisory services that are offered or by their interest in the environmental and sustainability problems of some communities and social groups.

- Education: undergraduate and graduate training for sustainability

This aspect aims to report on the most well-known training programs for sustainability at undergraduate and graduate level and to highlight the faculties and the departments or learning centers most representative for incorporating environmental and sustainability issues and relative to the academic structure at the universities.

In all cases it should be indicated whether in these undergraduate and graduate programs there is a predominant disciplinary, interdisciplinary or transdisciplinary approach such as, for example: sustainable development and environment, environmental quality management, risk management, climate change, social sciences and environmental economics, environmental education, local development, protection of biodiversity, management of ecosystems, organic farming, farming practices for cleaner production and eco-innovation and the like.

- Extension: university extension in sustainability issues

This exhibits the sustainability experiences of the extension programs and activities of the universities at local, provincial or national level. In particular, the most important cases of research-participative action, contribution to local development and community environmental education, which are relatively frequent could be highlighted.

- Administration: sustainable and environmental management systems

The best environmental or sustainable institution management practices and the organization of university campus are highlighted, taking into consideration not only their general organization but also their specific aspects. For example, references to good practice in laboratories, atmospheric emissions, disposal of waste water and chemical pollutants, storage of chemicals and hazardous products, greener production practices if they exist, the implementation of technical standards, the use of natural resources, office supplies, green areas and compost production, the landscape and the environment, risk management, conservation of cultural heritage, the connection with the urban environment and other aspects which are considered to be important.

Another method [7]-[9], which is widely used in universities comprises establishing environmental management systems which are applied to all the characteristic university teaching activities developed, such as: education processes for teaching-learning, teaching, research and university extension, the related products and services, such as the social dimension [10], of the University.

The environmental policy of each university is defined, ensuring that the provisions therein meet the following requirements [11]:

1) It is appropriate to the nature, magnitude and environmental impact of its activities, products and services.

2) Includes a commitment to continual improvement and prevention of pollution.

3) Includes a commitment to comply with the applicable legal requirements and with other requirements related to environmental aspects.

4) Provides the reference framework for establishing and reviewing the environmental objectives and goals. 
5) Documents, implements and maintains by way of systematic analysis review by management and internal audits, to ensure that it is appropriate.

6) Reports and communicates to all personnel that work at the institution or for it.

In order to achieve the aforementioned commitments, it is necessary for all students, workers and institutions involved in the activities at each university to collaborate [11].

\section{Discussion and Results}

In 2012 the indicators for Assessing the Contribution of Universities to Sustainable Development were agreed; these were classified into four groups named indicators for research, education, extension and connection and for administration. Table 1 shows the environmental and sustainable development indicators which are recommended to be chosen for assessing the contributions of universities in this respect [3].

In support of a proposal presented by the Universidad Internacional del Ecuador (UIDE) [International University of Ecuador], convened the national workshop "Building Indicators to Assess Sustainability in Universities]" which was held in November 2013 in UIDE. The objective of this workshop was to draft a proposal for interinstitutional agreement, on issues that would reveal the progress of sustainable development in universities over the previous ten years, in the framework of Agenda 21, and to create a set of sustainability indicators for

\section{Table 1. Environmental and sustainable development indicators for universities in Ecuador.}

\begin{tabular}{|c|c|}
\hline Classification of indicators & Indicators \\
\hline \multirow{5}{*}{$\begin{array}{l}\text { Research: Sustainability in } \\
\text { scientific research }\end{array}$} & Groups of multidisciplinary research on priority issues and points for sustainable development \\
\hline & Consolidated lines of research with interdisciplinary groups \\
\hline & Research for acknowledging, protecting and promoting local knowledge \\
\hline & Research in environmental technology which results in patents \\
\hline & Research for the risk assessment of technology which are promoted by the university \\
\hline \multirow{6}{*}{$\begin{array}{l}\text { Education: undergraduate } \\
\text { and graduate training for } \\
\text { sustainability }\end{array}$} & $\begin{array}{l}\text { Education programs which address issues of the United Nations Decade of Education for Sustainable } \\
\text { Development }\end{array}$ \\
\hline & Continuous education programs which address local priority needs \\
\hline & Education programs geared towards the valuation of local natural and cultural heritage \\
\hline & Environmental education programs by way of innovative pedagogical models \\
\hline & Education programs for sustainable development in open and distance modules. \\
\hline & Graduate studies in sustainable development \\
\hline \multirow{9}{*}{$\begin{array}{l}\text { Extension: university } \\
\text { extension in sustainability } \\
\text { issues }\end{array}$} & Dissemination activities to promote sustainable development \\
\hline & Extension programs which address priority problems for sustainable development in the country \\
\hline & Provision of institution professional services in the environmental field \\
\hline & Mass media for communication and dissemination of environmental knowledge \\
\hline & Social service programs aimed at sustainable community development \\
\hline & Participation in organized social movements for addressing environmental needs \\
\hline & $\begin{array}{l}\text { Public management tools for sustainable development based on proposals and/or outcomes of university } \\
\text { research }\end{array}$ \\
\hline & $\begin{array}{l}\text { Active participation in university networks and national and international bodies that count on programs } \\
\text { for sustainable development }\end{array}$ \\
\hline & Online University Press that addresses sustainable development issues \\
\hline \multirow{6}{*}{$\begin{array}{l}\text { Administration: sustainable } \\
\text { and environmental } \\
\text { management systems }\end{array}$} & Incorporation of sustainable development in institutional policies \\
\hline & Gender Equality in Executive Positions \\
\hline & Budget exercised in university programs for sustainable development \\
\hline & Water, paper and energy consumption at the University \\
\hline & Prevention of risks to health, the environment and heritage in IES [Higher Education Institutes] areas \\
\hline & Procurement and acquisitions which incorporate durability, efficiency and environmental security criteria \\
\hline
\end{tabular}


the Higher Education Institutes (IES being the Spanish acronym) in Ecuador. The summary table: Environmental and sustainable development indicators for universities in Ecuador (Table 1), which are shown below:

As can be seen, these indicators were designed in accordance with the conceptual framework for sustainable development in search of balance between the economic, social and ecological well-being. Similarly, they take into account the different intervention areas of the recognized universities such as science and research, technology, teaching and interaction with civil society. The theoretical framework upon which they were designed as well as the quality criteria used in their design makes them appropriate indicators which are extremely useful in assessing the contribution of universities to sustainable development.

\section{Conclusions}

Sustainability in scientific research is highlighted by the connection of works with the solution of existing problems, in the environmental and sustainability issues of some communities and social groups.

Undergraduate and graduate training for sustainability implies knowing the characteristics of the interdisciplinary or transdisciplinary approaches aimed at specific transversal issues such as, for example, sustainable development and environment, environmental quality management, risk management, climate change, social sciences and environmental economics, environmental education, local development, protection of biodiversity, management of ecosystems, organic farming, farming practices for cleaner production and eco-innovation and the like.

University extension in sustainability issues allows for highlighting the most important research—participative action cases, contribution to local development and community environmental education. Sustainable institutional management highlights the best environmental practices or sustainable institutional management and the organization of university campus.

A very effective method is to incorporate the environmental management systems that are applied to all the developed characteristic activities of university teaching such as: the teaching-learning education processes, teaching, research and university extension, the related products and services as well as the social dimension of the University.

\section{References}

[1] Lozano, R.S., Morillo, F., De Filippo, D., Muñoz, M.T.F. and Caridad, I.G. (2006) Indicadores de colaboracióncientífica inter-centrosenlospaíses de América Latina. DIALNET. https://dialnet.unirioja.es/servlet/articulo?codigo=1992292

[2] Bice, S. and Hamish, C. (2016). University Sustainability Reporting: Taking Stock of Transparency. Tertiary Education and Management, 22, 1-18. http://dx.doi.org/10.1080/13583883.2015.1115545

[3] ISCN-GULF (2012) Universidad Internacionaldel Ecuador. ISCN-GULF Sustainable Campus Charter Report 2012. http://www.international-sustainable-campus-network.org/charter-and-guidelines/charter-reports/universidad-internaci onal-del-ecuador

[4] GUPES (2011) Proceedings of the High Level Planning, Consultative, Sharing and Learning Meeting for University Leaders. http://gupes.org/themes/127/userfiles/download/2012/8/8/ptxaqs091cpeia2.pdf

[5] ARIUSA (2013) Red de Indicadores de Sostenibilidaden las Universidades. Alianza de Redes Iberoamericana de Universidadespor la Sustentabilidad y el Ambiente. http://ariusa.net/es/redes

[6] RISU (2014) RISU Project. Development of Indicators to Assess the Implementation of Sustainability Policies in Latin American Universities.

https://www.google.com.ec/search?hl=en\&site=webhp\&source=hp\&q=red+de+indicadores+uiversitarios+risu\&oq=re

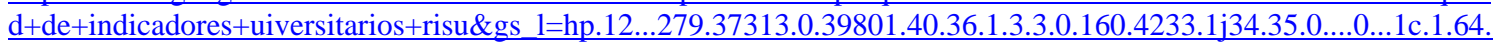
hp..1.28.2844.ehCN3H8SGpY

[7] Hák, T., Janoušková, S. and Moldan, B. (2016) Sustainable Development Goals: A Need for Relevant Indicators. Ecological Indicators, 60, 565-573. http://dx.doi.org/10.1016/j.ecolind.2015.08.003

[8] Mattos, R., Gomes, R. and Ribeiro da Silva, G. (2016) Sustainability Insights from the Mission Statements of Leading Brazilian Universities. International Journal of Educational Management, 30, 403-415. http://www.emeraldinsight.com/doi/abs/10.1108/IJEM-05-2014-0065\#

[9] Beynaghi, A., et al. (2016) Future Sustainability Scenarios for Universities: Moving beyond the United Nations Decade of Education for Sustainable Development. Journal of Cleaner Production, 112, 3464-3478.

http://www.sciencedirect.com/science/article/pii/S0959652615015899

http://dx.doi.org/10.1016/j.jclepro.2015.10.117 
[10] Del Sordo, C., Farneti, F., Guthrie, J., Pazzi, S. and Siboni, B. (2016) Social Reports in Italian Universities: Disclosures and Preparers' Perspective. Meditari Accountancy Research, 24, 91-110. http://www.emeraldinsight.com/doi/abs/10.1108/MEDAR-09-2014-0054

[11] Gutiérrez, L.R., Céspedes, D.G. and Cazorla, L.L. (2014) Cuadernosdel Contrato Social por la Educación N 10. Contrato Social por la Educación Ecuador. http://contratosocialecuador.org/images/publicaciones/cuadermos/10.pdf\#page=89 